\title{
Flow-Injection Solid Phase Partial Least-Squares Spectrophotometric Simultaneous Determination of Iron, Nickel and Zinc
}

\author{
Leonardo S. G. Teixeira ${ }^{a, c *}$, Antonio C. S. Costa ${ }^{a}$, Salvador Garrigues ${ }^{b}$ and Miguel de la Guardia \\ ${ }^{a}$ Instituto de Química, Universidade Federal da Bahia, 40170-290, Salvador - BA, Brazil \\ ${ }^{b}$ Department of Analytical Chemistry, University of Valencia, C/ Doctor Moliner 50, 46100, Valencia, Spain \\ ${ }^{c}$ Universidade Salvador - Unifacs, Av. Cardeal da Silva 747, 40220-141, Salvador - BA, Brazil
}

\begin{abstract}
Um método de calibração multivariada PLS-2 foi desenvolvido para a determinação simultânea de ferro, níquel e zinco em misturas ternárias utilizando a espectrofotometria em fase sólida acoplada à análise em fluxo. $\mathrm{Fe}(\mathrm{II}), \mathrm{Ni}$ (II) e $\mathrm{Zn}$ (II) formam complexos coloridos com 1-(2-tiazolilazo)-2naftol (TAN), imobilizado em sílica funcionalizada $\mathrm{C} 18 \mathrm{em} \mathrm{pH}$ 6,4. O procedimento proposto foi baseado nas diferentes razões de reação/retenção dos íons estudados sobre o suporte sólido. Os dados espectrofotométricos dos analitos, fixados no suporte sólido, foram obtidos entre 400 e 800 $\mathrm{nm}$ como função do tempo e um algoritmo utilizando o método dos mínimos quadrados parciais (PLS-2) foi usado para prever a concentração dessas espécies em amostras sintéticas. O lote de calibração empregado foi constituído por 8 misturas ternárias e um branco. Misturas contendo 0,040 a $0,20 \mathrm{mg} \mathrm{L}^{-1}$, de cada espécie, foram resolvidas satisfatoriamente, usando 3 fatores para cada analito com dados espectrofotométricos obtidos em uma faixa de comprimento de onda entre 560 e $650 \mathrm{~nm}$.
\end{abstract}

A PLS-2 multivariate calibration method has been developed for the simultaneous determination of iron, nickel and zinc in ternary mixtures by solid phase spectrophotometry associated with flow injection analysis. $\mathrm{Fe}(\mathrm{II}), \mathrm{Ni}(\mathrm{II})$ and $\mathrm{Zn}$ (II) form color complexes with 1-(2-thiazolylazo)-2naphthol (TAN), immobilized on a $\mathrm{C} 18$ bonded silica support, at $\mathrm{pH}$ 6.4. The proposed procedure is based on the different reaction/retention ratios of the studied ions on the solid support. Bilinear spectrophotometric data of the analytes, fixed in the solid support, were recorded in the 400-800 $\mathrm{nm}$ wavelength range as a function of time and a partial least squares (PLS-2) algorithm was used to predict results of synthetic samples. The calibration set employed was integrated by 8 ternary mixture standards and a blank solution. Mixtures containing 0.040 to $0.20 \mathrm{mg} \mathrm{L}^{-1}$, of each species, were successfully resolved, using 3 factors for each analyte and a restricted number of absorbance data obtained in the wavelength range from 560 to $650 \mathrm{~nm}$.

Keywords: solid phase spectrophotometry, FIA, multicomponent determination, partial leastsquare analysis

\section{Introduction}

Solid phase spectrophotometry (SPS) provides effective methods to combine metal ion preconcentration and their spectrophotometric determination, by integrating the formation of colored complexes and their fixation on the surface of a solid support placed inside the measurement cell. ${ }^{1,2}$ The coupling between flow injection analysis (FIA) and SPS (FI-SPS) makes it unnecessary to reach equilibrium conditions, thus providing faster and more

\footnotetext{
*e-mail: 1sgt@ufba.br
}

selective methods than those found in batch conditions. Additionally, it offers a simple and easy way of automation and provides low detection limits, small amounts of samples and reagents ${ }^{3}$ being employed.

Since flow injection analysis was introduced, the simultaneous determination of several analytes in a same sample has been a challenge in order to make FIA competitive with other analytical techniques. In this way, the use of SPS and FIA has been applied in several studies for the determination of binary mixtures of metal ions, ${ }^{4-7}$ amines $^{8}$ and mixtures of dyes. ${ }^{9-11}$

Approaches employed for multicomponent determination in solution can be also applied in FI-SPS. 
Thus, several processes, without a previous separation or masking steps, can be employed based on multiwavelength detection with mathematical data processing.

There are various mathematical algorithms and chemometric methods associated with the advanced analytical instrumentation that allow on-line multicomponent analysis. These methods are based on calibration procedures, such as principal component regression (PCR) ${ }^{12}$ and partial least-squares (PLS) which, in fact, have been employed in our research for the simultaneous determination of four carbamate pesticides ${ }^{13}$ and five phenolic compounds. ${ }^{14}$

In the present work, 1-(2-thiazolylazo)-2-naphthol (TAN), immobilized on a C18 bonded silica support, was employed for the PLS spectrophotometric determination of ternary mixtures of $\mathrm{Fe}, \mathrm{Ni}$ and $\mathrm{Zn}$ in water based in previous studies ${ }^{3,15}$ which showed that $\mathrm{Fe}(\mathrm{II}), \mathrm{Ni}(\mathrm{II})$ and $\mathrm{Zn}$ (II) were retained on TAN-C18 forming complexes in the 5.5 to $8.0 \mathrm{pH}$ range.

\section{Experimental}

\section{Reagents and solutions}

All solutions were prepared with analytical grade reagents and high purity de-mineralized water. Iron, nickel and zinc standard solutions $\left(0.040-0.20 \mathrm{mg} \mathrm{L}^{-1}\right)$ were prepared by dilution of $1000 \mathrm{mg} \mathrm{L}^{-1}$ stock ones. The buffer employed was $1.0 \mathrm{~mol} \mathrm{~L}^{-1}$ hexamine with $\mathrm{pH}$ adjusted to 6.4 with $\mathrm{HCl}$. TAN solution was prepared by dissolving $1.0 \mathrm{mg}$ of 1-(2-thiazolylazo)-2-naphthol Merck (Darmstadt, Germany) in $1 \mathrm{~mL}$ of ethanol and completing the volume to $100 \mathrm{~mL}$ with a $1 \%(\mathrm{w} / \mathrm{v})$ Triton X-100 Panreac (Barcelona, Spain) solution. An $\mathrm{HCl}$ solution $\left(0.5 \mathrm{~mol} \mathrm{~L}^{-1}\right)$ was prepared by proper dilution of concentrated acid. Hydroxylammonium chloride $1 \%(\mathrm{w} / \mathrm{v})$ was used to guarantee the total iron reduction to iron (II). TAN reagent was immobilized on-line in C18 bonded silica $(60-100 \mu \mathrm{m})$ obtained from Waters Sep-Pak cartridges and placed inside the flow cell. De-mineralized water was used as the carrier stream.

The chromogenic reagent was immobilized on $35 \mathrm{mg}$ of the solid support contained in the flow cell by pumping the TAN solution through the cell at $1.5 \mathrm{~mL} \mathrm{~min}^{-1}$ during 5 min. Afterwards, the flow cell was washed with $\mathrm{HCl}$ and water to remove the excess of TAN and then it was inserted in the optical path of the spectrophotometer.

Standard solutions and synthetic mixtures of $\mathrm{Fe}(\mathrm{II})$, $\mathrm{Ni}(\mathrm{II})$ and $\mathrm{Zn}$ (II) were prepared by adding appropriate aliquots of the metal reference solutions to $50-\mathrm{mL}$ volumetric flasks containing $5 \mathrm{~mL}$ of hexamine buffer and
$5 \mathrm{~mL}$ of hydroxylammonium. The blank solution was prepared in de-mineralized water, containing buffer and the reducer.

\section{Apparatus and software}

The set-up consisted of a Hewlett-Packard (Avondale, PA, USA) Model HP8452A diode array-spectrophotometer, equipped with HP89530A MS-DOS UV-visible software, and a home-made flow cell of $1.0 \mathrm{~mm}$ optical path and $78 \mathrm{~mm}^{2}$ cross section. ${ }^{3}$ A peristaltic pump Gilson Miniplus 2 (Villiers Le Bel, France) equipped with flexible poly-vinyl chloride tube was employed for carrier transport and a sliding bar commutator ${ }^{16}$ was used for standard and sample injection. Loops and connections were made from PTFE tubes with $0.8 \mathrm{~mm}$ id.

Absorption spectra were recorded and processed with the help of the spectrophotometer software. Data were transferred to an ASCI format and processed using a PC/ AT 486 personal computer equipped with a PLS software from NICOLET (Madison, USA).

\section{Flow diagram and procedure}

The loop L, of the manifold depicted in Figure 1, was filled with $\mathrm{HCl}$ and simultaneously the sample solution was flowed through the analytical path at $2.0 \mathrm{~mL} \mathrm{mim}^{-1}$. $\mathrm{Fe}$ (II), $\mathrm{Ni}(\mathrm{II})$ and $\mathrm{Zn}(\mathrm{II})$, present in the samples, reacted with the chromogenic reagent immobilized on the $\mathrm{C} 18$ beads and these ions were retained on the solid support forming the respectively complexes. Simultaneously, spectrophoto-

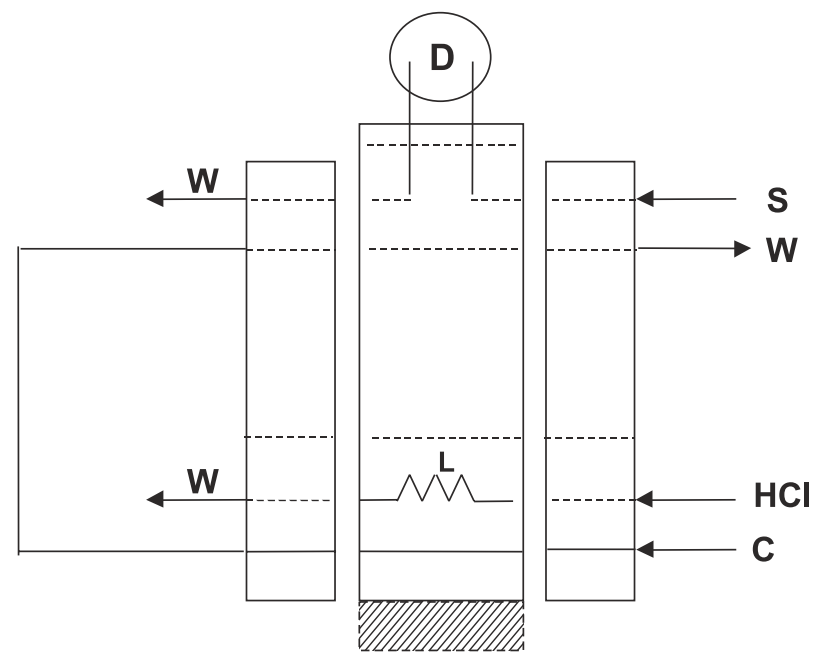

Figure 1. Set-up employed for FI-SPS determination of $\mathrm{Fe}(\mathrm{II}), \mathrm{Ni}(\mathrm{II})$ and $\mathrm{Zn}(\mathrm{II})$. S - sample (buffered at $\mathrm{pH}$ 6.4); C - carrier stream (water); $\mathrm{L}$ - $\mathrm{HCl}$ loop $(625 \mathrm{~mL})$; D - spectrophotometer equipped with a homemade flow cell; $\mathrm{W}$ - waste. $0.5 \mathrm{~mol} \mathrm{~L}^{-1} \mathrm{HCl}$ was employd as eluent. 
metric measurements were carried out in the $400-800 \mathrm{~nm}$ wavelength range with a resolution of $2 \mathrm{~nm}$ using a scan acquisition time of $9 \mathrm{~s}$ in consecutive cycles of $10 \mathrm{~s}$. After $100 \mathrm{~s}$ acquiring time of spectra, a $625 \mu \mathrm{L} \mathrm{HCl}$ volume was inserted in the carrier by sliding the commutator central bar, and transported towards the flow cell in order to provide the elution of the ions without removing the TAN chromogenic reagent. Data found for a calibration set (see Table 1) of 8 ternary mixtures of the ions studied, considered at two concentration levels, and a blank containing hexamine buffer and hydroxylammonium, were employed to obtain the PLS-2 parameters which were used in the prediction of the concentration of unknown samples.

Table 1. Composition of the calibration matrix employed for the PLS spectrophotometric determination of iron, nickel and zinc using FI-SPS.

\begin{tabular}{clll}
\hline & \multicolumn{3}{c}{ Amount added $/ \mathrm{mg} \mathrm{L}^{-1}$} \\
\hline Standard & $\mathrm{Fe}$ & $\mathrm{Ni}$ & $\mathrm{Zn}$ \\
\hline 1 & 0.040 & 0.040 & 0.040 \\
2 & 0.040 & 0.040 & 0.20 \\
3 & 0.040 & 0.20 & 0.040 \\
4 & 0.20 & 0.040 & 0.040 \\
5 & 0.040 & 0.20 & 0.20 \\
6 & 0.20 & 0.20 & 0.040 \\
7 & 0.20 & 0.040 & 0.20 \\
8 & 0.20 & 0.20 & 0.20 \\
Blank & 0 & 0 & 0 \\
\hline
\end{tabular}

\section{Results and Discussion}

\section{Reaction between the metal ions and TAN-C18}

TAN, immobilized on a C18 support, was very stable in neutral and acidic solutions, allowing the use of the modified solid phase for more than 100 measurements without affecting the retention of analytes. Using $0.5 \mathrm{~mol} \mathrm{~L}^{-1}$ $\mathrm{HCl}$ as eluent of the ions, the removal of the TAN reagent was not perceptible during the time of analysis.

Iron(II), nickel(II) and zinc(II) complexes with TAN, adsorbed on $\mathrm{C} 18$, present a red color and showed absorption maximum at $580 \mathrm{~nm}$. However, as can be see in Figure 2, the spectra of all the complexes studied are highly overlapped, thus prohibiting the differentiation among Fe(II), $\mathrm{Ni}$ (II) and $\mathrm{Zn}$ (II) in samples containing mixtures of these elements. The effect of $\mathrm{pH}$ on the reaction/retention of $\mathrm{Fe}(\mathrm{II})$, $\mathrm{Ni}$ (II) and $\mathrm{Zn}$ (II) on C18-TAN was first studied within the 4.5 to 8.5 range. No significant variation in the retention efficiency was observed in the 6.4 to $7.8 \mathrm{pH}$ range for $\mathrm{Fe}(\mathrm{II})$, 5.5 to $7.3 \mathrm{pH}$ range for $\mathrm{Ni}(\mathrm{II})$, and in the 5.8 to $6.7 \mathrm{pH}$ range for $\mathrm{Zn}(\mathrm{II})$. Thus, in further experiments an hexamine buffer solution at $\mathrm{pH} 6.4$ was added to the samples.
Figure 3 shows the evolution, as a function of time, of the absorbance of each colored species at its maximum absorbance wavelength and, as it can be seen, the retention/ reaction processes take place with different relative sensitivities and with the rate of the process being similar for $\mathrm{Fe}(\mathrm{II})$ and $\mathrm{Ni}$ (II) but different for $\mathrm{Zn}$. In principle, this fact can be used to do the simultaneous determination of $\mathrm{Fe}(\mathrm{II}), \mathrm{Ni}(\mathrm{II})$ and $\mathrm{Zn}$ (II) in samples containing these ions, in order to take advantage of the differences of behavior of the three elements considered (see Figure 3).

\section{PLS-1 treatment of spectrophotometric data}

Mixtures of the three ions considered, at two concentration levels, were employed as the calibration set (see Table 1). 8 standards plus a blank solution were

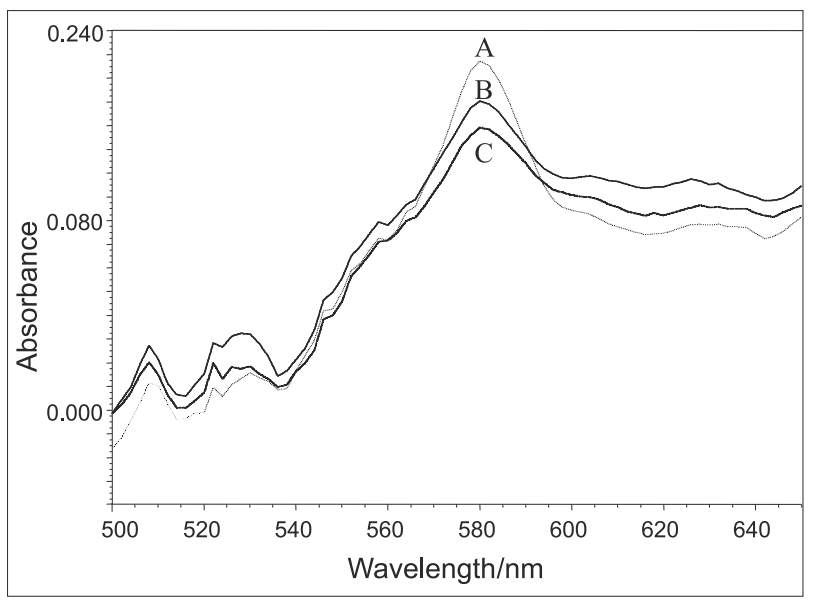

Figure 2. Absorbance spectra of complexes formed between TAN-C18 and studied ions at pH 6.4. (A) $\mathrm{Zn}(\mathrm{II})$, (B) $\mathrm{Fe}$ (II) and (C) $\mathrm{Ni}(\mathrm{II})$.

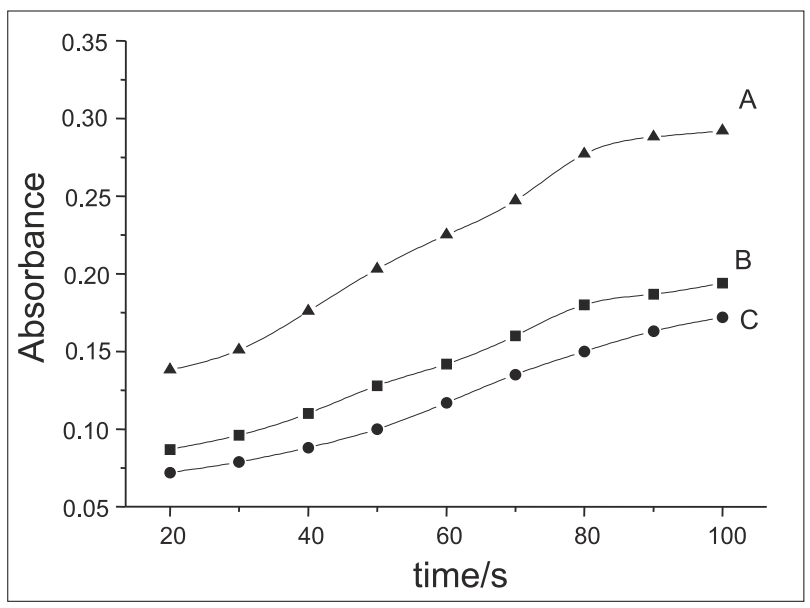

Figure 3. Absorbance signals at $580 \mathrm{~nm}$ obtained for the complexes formed with TAN-C18 as a function of time. (A) Zn(II), (B) Fe(II) and (C) $\mathrm{Ni}(\mathrm{II})$. 
introduced into the cell and absorbance data were taken from 400 to $800 \mathrm{~nm}$ under wavelength intervals of $2 \mathrm{~nm}$. Thus 201 points, which were measured every $10 \mathrm{~s}$ for a period of $100 \mathrm{~s}$, were obtained for each solution. Spectral data found for each measurement time were mean centered and variance scaled and then treated by PLS-1. The evaluation of the model by cross-validation (see Table 2) showed difficulties to resolve correctly these ternary mixtures due to the overlap of the different ion spectra (see Figure 2). At the best conditions, corresponding to measurements carried-out after $30 \mathrm{~s}$, PLS-1 provided excellent values for Fe(II) but mean errors higher than $10 \%$ for $\mathrm{Ni}(\mathrm{II})$ and $\mathrm{Zn}(\mathrm{II})$. So, PLS-2 treatment was evaluated, by considering data found at different times, as an alternative to determine simultaneously $\mathrm{Fe}(\mathrm{II}), \mathrm{Ni}$ (II) and $\mathrm{Zn}$ (II) with immobilized TAN on C18 beads in spite of the strong overlapping between spectra of the complexes of the elements considered.

Table 2. Relative mean standard errors of prediction, as a function of the measurement time, found by cross validation of the calibration data employed for PLS-1 treatment of mixtures of Fe, Ni and Zn.

\begin{tabular}{ccrcc}
\hline & \multicolumn{3}{c}{ Relative MEP $(\%)$} & \\
\cline { 2 - 4 } Time/s & \multicolumn{1}{c}{$\mathrm{Fe}$} & \multicolumn{1}{c}{$\mathrm{Ni}$} & $\mathrm{Zn}$ & Nr. of factors* \\
\hline 20 & 42.8 & 5.3 & 41.3 & $1,2,1$ \\
30 & 0.80 & 12.6 & 10.4 & $4,2,2$ \\
40 & 60.6 & 3.4 & 19.8 & $1,3,2$ \\
50 & 32.0 & 12.8 & 4.5 & $2,4,4$ \\
60 & 4.5 & 16.3 & 19.4 & $3,3,2$ \\
70 & 15.4 & 112.4 & 22.3 & $2,1,2$ \\
80 & 14.5 & 91.9 & 22.0 & $2,1,2$ \\
90 & 13.5 & 104.3 & 39.1 & $2,1,2$ \\
100 & 11.4 & 105.4 & 24.8 & $2,1,2$ \\
\hline
\end{tabular}

* $\mathrm{Nr}$ of factors corresponds to the best number of factors for data evaluation, by PLS-1, of mixtures of the three ions studied.

\section{PLS-2 treatment of spectrophotometric data}

After $20 \mathrm{~s}$, injected sample solutions reached the flow cell providing significant retention of the analytes. Spectral data found, between this time and 100s at 10s intervals, were grouped (see Figure 4) obtaining new files containing 9 spectra in a sequential order. When spectra were collected from 400 to $800 \mathrm{~nm}$ wavelength range, $201 \mathrm{x} 9$ absorbance data points were obtained. These data were mean centered and variance scaled, being then treated by PLS.

Using the whole wavelength range, relative mean errors of prediction of $6.2 \%$ for $\mathrm{Fe}(\mathrm{II}), 29.8 \%$ were found for $\mathrm{Ni}$ (II) and $2.2 \%$ for $\mathrm{Zn}$ (II) for 3, 2 and 3 considered factors respectively. These results indicate some advantages offered by the simultaneous consideration of spectral data found at different measurement times, as compared with PLS-1 data treatment which provided mean error higher than $10 \%$ for $\mathrm{Ni}(\mathrm{II})$ and $\mathrm{Zn}(\mathrm{II})$. Additional tests were carried out to improve the obtained results using PLS-2 treatment of spectrophotometric data.

In order to select the best spectral range for PLS data evaluation, several restricted intervals were considered, by reducing from 201 to 46 absorbance points. Table 3 shows that the lowest mean errors obtained for the calibration set are those found between 560 and $650 \mathrm{~nm}$, due probably to the high background of the solid support under $560 \mathrm{~nm}$ and above $650 \mathrm{~nm}$.

The percentage of residual variance explained in the cross-validation process was evaluated for the concentration matrix and it was found that the use of 4 factors provided explained levels higher than $93 \%$ for the three elements considered. On the other hand, it was found (see Figure 5a) that the mean standard error of prediction (MEP) for the cross-validation process reached a minimum value for 4 factors in all cases. However Figure 5b shows that 3 factors

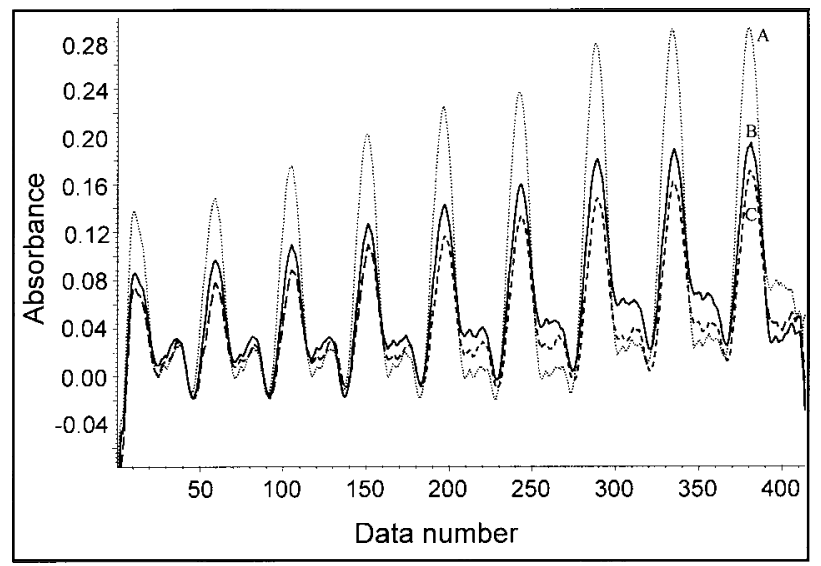

Figure 4. Absorption recording of data found for (A) $\mathrm{Zn}$ (II), (B) Fe(II) and (C) $\mathrm{Ni}(\mathrm{II})$ at concentration levels of $0.10 \mathrm{mg} \mathrm{L}^{-1}$ measured 9 times in the range $560-650 \mathrm{~nm}$. Each 46 points set corresponds to successive measurement times collect at intervals of $10 \mathrm{~s}$.

Table 3. Effect of the spectral range on the relative MEP obtained for the calibration set using PLS-2. Data were obtained by accumulating 9 scans in cycles of $10 \mathrm{~s}$.

\begin{tabular}{lccccc}
\hline & \multicolumn{4}{c}{ Relative MEP } & \\
\cline { 3 - 5 } $\begin{array}{l}\text { Wavelength } \\
\text { range/nm }\end{array}$ & $\begin{array}{l}\text { No. of } \\
\text { points }\end{array}$ & $\mathrm{Fe}$ & $\mathrm{Ni}$ & $\mathrm{Zn}$ & $\begin{array}{c}\text { No. of } \\
\text { factors* }\end{array}$ \\
\hline $400-800$ & 201 & 6.2 & 29.8 & 2.2 & $3,2,3$ \\
$400-650$ & 126 & 6.1 & 49.0 & 5.1 & $3,2,3$ \\
$560-800$ & 121 & 2.7 & 13.8 & 8.2 & $3,2,2$ \\
$500-700$ & 101 & 8.7 & 9.0 & 19.3 & $3,3,2$ \\
$560-650$ & 46 & 4.9 & 0.42 & 0.37 & $3,3,3$ \\
\hline
\end{tabular}

*The number of factors was chosen for each determination to obtain the minimum mean error of prediction (MEP) for the validation set. In each instance the three values given refer to iron, nickel and zinc respectively. 
Table 4. Results obtained for the simultaneous determination of iron, nickel and zinc in synthetic mixtures by FI-SPS using PLS-2.

\begin{tabular}{|c|c|c|c|c|c|c|c|c|c|}
\hline \multirow[t]{2}{*}{ Mixture } & \multicolumn{3}{|c|}{ Amount added/ $\mathrm{mg} \mathrm{L}^{-1}$} & \multicolumn{3}{|c|}{$\begin{array}{l}\text { Amount found/ } \mathrm{mg} \mathrm{L}^{-1} \\
\text { (3 factors) }\end{array}$} & \multicolumn{3}{|c|}{$\begin{array}{l}\text { Amount found/ } \mathrm{mg} \mathrm{L}^{-1} \\
\text { (4 factors) }\end{array}$} \\
\hline & $\mathrm{Fe}$ & $\mathrm{Ni}$ & $\mathrm{Zn}$ & $\mathrm{Fe}$ & $\mathrm{Ni}$ & $\mathrm{Zn}$ & $\mathrm{Fe}$ & $\mathrm{Ni}$ & $\mathrm{Zn}$ \\
\hline Sample 1 & 0.10 & 0.10 & 0.050 & 0.090 & 0.094 & 0.045 & 0.091 & 0.092 & 0.046 \\
\hline Sample 2 & 0.080 & 0.040 & 0.040 & 0.086 & 0.036 & 0.038 & 0.086 & 0.038 & 0.037 \\
\hline Sample 3 & 0.10 & 0.12 & 0.060 & 0.093 & 0.11 & 0.065 & 0.095 & 0.11 & 0.067 \\
\hline Sample 4 & 0.050 & 0.080 & 0.080 & 0.054 & 0.080 & 0.069 & 0.056 & 0.078 & 0.070 \\
\hline Sample 5 & 0.12 & 0.12 & 0.060 & 0.11 & 0.11 & 0.062 & 0.11 & 0.11 & 0.062 \\
\hline
\end{tabular}

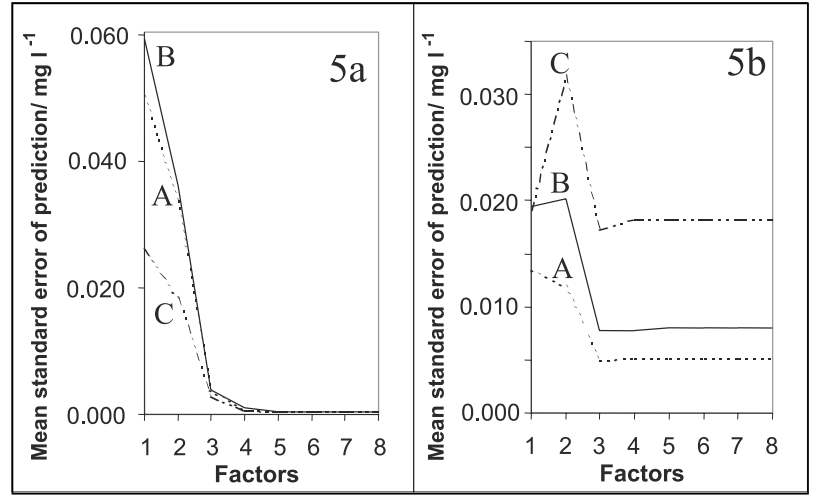

Figure 5. Mean standard error of prediction, expressed in $\mathrm{mg} \mathrm{L}^{-1}$, for each ion considered as a function of the number of factors: (A) $\mathrm{Zn}(\mathrm{II})$, (B) $\mathrm{Fe}(\mathrm{II}),(\mathrm{C}) \mathrm{Ni}(\mathrm{II})$. 5a: cross-validation of the calibration set. 5b: prediction of the validation-set.

provided the lowest MEP's for all the three ions considered in the case of concentration prediction for samples included in the validation set. So, from these facts, it was concluded that the use of 3 factors for $\mathrm{Fe}$ (II), $\mathrm{Ni}$ (II) and $\mathrm{Zn}$ (II) is enough to obtain accurate results in the analysis of water samples containing mixtures of these elements.

\section{Determination of $\mathrm{Fe}(\mathrm{II}), \mathrm{Ni}(\mathrm{II})$ and $\mathrm{Zn}(\mathrm{II})$ in water samples}

In order to test the performance of the proposed method, the aforementioned model was applied to predict the concentrations of the three ions in five synthetic mixtures, not employed in the calibration process. Results shown in Table 4 evidenced the ability of this method to obtain accurate results. By applying the $t_{95 \%}$ paired test, it can be said that there is no significant difference between the obtained values using the proposed procedure and the amount added. On the other hand, as indicated before, the use of 3 factors provided the best results.

\section{Conclusions}

$\mathrm{Fe}(\mathrm{II}), \mathrm{Ni}(\mathrm{II})$ and $\mathrm{Zn}$ (II) are retained on TAN immobilized in $\mathrm{C} 18$ bonded silica, forming complexes allowing in situ analyte separation and concentration of these ions from a water matrix.

The use of a multivariate calibration method, in the reduced range of 560-650 nm, in association with solid phase spectrophotometry and flow injection analysis, was appropriate for the determination of iron, nickel and zinc using a PLS-2 algorithm.

The method developed takes advantage of sensitivity and selectivity enhancements provided by the use of solid phase spectrophotometry and also of the benefits of multivariate calibration methods, i.e. the rapid determination of the analytes in a mixture without previous masking, preconcentration or separation steps.

\section{Acknowledgements}

Authors acknowledge Fundação Coordenação de Aperfeiçoamento de Pessoal de Nível Superior (CAPES, Brazil), Conselho Nacional de Desenvolvimento Científico e Tecnológico (CNPq, Brazil) and financial support of the Spanish DGES Project PB 96-0779.

\section{References}

1. Yoshimura, K.; Waki, H.; Talanta 1985, 32, 345.

2. Ortega-Barrales, P.; Molina-Dias, A.; Pascual-Reguera, M. I.; Capitán-Vallvey, L. F.; Anal. Chim. Acta 1997, 353, 115.

3. Teixeira, L.S.G.; Rocha, F.R.P.; Reis, B.F.; Korn, M.; Ferreira S.L.C.; Costa, A.C.S.; Anal. Chim. Acta 1999, 383, 307.

4. Matsuoka, S.; Tennichi, Y.; Takehara, K.; Yoshimura, K.; Analyst 1999, 124, 787.

5. Vereda, E.; Rios, A.; Valcarcel, M.; Analyst 1997, 122, 85.

6. Maksimova, M.; Morosanova, E.I.; J. Anal. Chem. 1994, 49, 543.

7. Valencia, M.C.; Budra, S.; Bosque-Sendra, J.M.; Anal. Chim. Acta 1996, 327, 73.

8. Fernández-Band, B.; Lázaro, F.; Luque de Castro, M.D.; Valcarcel, M.; Anal. Chim. Acta 1990, 229, 177.

9. Capitán-Vallvey, L.F.; Fernández, M.D.; de Orbe I.; Avidad, R.; Talanta 1998, 47, 861. 
10. Capitán-Vallvey, L.F.; Navas-Iglesias, N.; de Orbe-Payá, I.; Castañeda, R.A.; Talanta 1996, 43, 1457.

11. Capitán-Vallvey, L. F.; Deheidel, M.K.A.; de Orbe I.; Avidad, R.; Analyst, 1999, 124, 49.

12. Cadet, F.; Bertrand, D.; Robert, P.; Maillot, J.; Dieudonne J.; Rouch, C.; Appl. Spectrosc. 1991, 45, 166.

13. Garcia, J.M.; Jiménez, A.I.; Arias, J.J.; Khalaf, K.D.; MoralesRubio, A.; de la Guardia, M.; Analyst 1995, 120, 313.
14. de la Guardia, M.; Khalaf, K.D.; Hansan, B.A.; Morales-Rubio, A.; Arias, J.J.; Garcia-Fraga, J.M.; Jimenez, A.I.; Jimenez, F.; Analyst 1996, 121, 1321.

15. Teixeira, L.S.G.; Rocha, F.R.P.; Korn, M.; Reis, B.F.; Ferreira, S.L.C.; Costa, A.C.S.; Talanta 2000, 51, 1027.

16. Reis, B.F.; Jacintho, A.O.; Mortatti, J. Krug, F.J.; Zagatto, E.A.G.; Bergamim Fo ${ }^{\circ}$ H.; Pessenda L.C.R.; Anal. Chim. Acta 1981, 123, 221. 